Jurnal Ilmu Dan Teknologi Kesehatan

Vol 7, No 2, Maret 2020,

ISSN: 2338-9095 (Print)

ISSN: 2338-9109 (online)

\title{
Continuum of Care as An Effort to Reduce Stunting Events in Karawang District
}

\author{
Siti Sopiatun, Sri Maryati \\ STIKes Kharisma Karawang \\ Email:karsi.nasya@gmail.com
}

\begin{abstract}
Article history
Posted, Oct 7th, 2019

Reviewed, Feb 25th, 2020

Received, March 10th, 2020
\end{abstract}

\begin{abstract}
Stunting is a condition of failure to thrive in children under five years due to chronic malnutrition so that the child is too short for his age. Malnutrition appears when the baby is in the womb and the early period after the baby is born. The purpose of this study is how the Continuum of Care Program is implemented, analyze cross-sectoral, and cross-program support in nutritional surveillance to prevent and manage stunting. The study design used a cross-sectional survey approach. The results of research from 6 Puskesmas working areas showed the highest number in Puskesmas Lemah Duhur with an incidence of stunting $81 \%$, had a continuum of ineffective stunting treatments with an average of 63.84 and less available treatment centers with an average of 63.75. There are obstacles in sending information that occurs from the Puskesmas to posyandu cadres related to stunting. The range of treatments in providing effective care and place of care has the most significant impact on maternal health, the health of newborns, and children related to the incidence of stunting in each region. Collaboration and cross-sector programs are needed in stunting prevention by the government.
\end{abstract}

Keywords: the continuum of care; stunting; children

\begin{abstract}
ABSTRAK
Stunting adalah kondisi gagal tumbuh pada anak di bawah lima tahun karena kekurangan gizi kronis sehingga anak terlalu pendek untuk usianya. Malnutrisi disebabkan saat bayi di dalam rahim dan pada periode awal setelah bayi lahir. Tujuan penelitian ini adalah bagaimana Program perawatan berkelanjutan diimplementasikan serta menganalisis dukungan lintas-sektor dan lintas-program dalam pengawasan gizi sebagai upaya untuk mencegah dan mengelola stunting. Desain penelitian menggunakan pendekatan survei cross sectional. Hasil penelitian dari 6 wilayah kerja Puskesmas didapatkan angka tertinggi di Puskesmas Lemah Duhur dengan kejadian stunting $81 \%$, memiliki perawatan stunting berkelanjutan yang kurang efektif dengan rata-rata 63,84 dan pusat perawatan kurang tersedia dengan rata-rata 63,75. Terdapat hambatan dalam pengiriman informasi yang terjadi dari Puskesmas ke kader posyandu terkait dengan stunting. Rangkaian perawatan dalam memberikan perawatan yang efektif dan tempat perawatan memiliki dampak terbesar pada kesehatan ibu, kesehatan bayi baru lahir dan anak-
\end{abstract}


anak terkait dengan kejadian stunting di setiap wilayah. Perlu adanya kolaborasi dan program lintas sektor dalam pencegahan stunting yang dilakukan oleh pemerintah.

Kata kunci: perawatan berkelanjutan; stunting; anak

\section{INTRODUCTION}

Stunting is a condition of failure to thrive in children under five (babies under five years old) due to chronic malnutrition so that the child is too short for his age. The baby causes malnutrition in the womb and the early period after the baby is born, but the incidence of stunting can be seen after the baby is two years old. Stunting can increase the risk of disease, body damage that is not settled, brain development that is not optimal, affecting cognitive abilities, and death in children (UNICEF 2013).

An estimated 165 million children under five years of age are stunted, with a heightfor-age Z-score (HAZ) below -2 (i.e., more than two standard deviations below the population median). However, a larger number of children with HAZ $>-2$ still have weak linear growth and are therefore experiencing stunting (UNICEF, 2012). Stunting is caused by multi-dimensional factors and is not only caused by malnutrition factors experienced by pregnant women and children under five years. The most decisive intervention to be able to reduce the stunting prevalence needs to be done in the First 1,000 Days of Life (HPK) of toddlers (TNP2K, 2017).
Nutritional status in toddlers needs to get serious attention from parents. Malnutrition in toddlers can cause irreversible. Stunting is an indicator of prolonged malnutrition (Wobay A, Member Y, Tsegaye D, 2017).

According to the results of the study explained that the prevalence of stunting is still high, around 15\%. Therefore, improving adolescent nutritional status is very important through the provision of comprehensive and routine nutrition assessment and counseling services for adolescents at the community, school, and health facility levels (Fikadu T, Assegit S, Dube L 2014). In line with other studies, besides irregular supplementary feeding methods, family size, number of children under five in the household, mother's work, duration of exclusive breastfeeding, duration of breastfeeding, and related to stunting (Dinkes Jawa Barat, 2018).

Over the past decade in Indonesia, there has been little change in the national prevalence of child stunting, which is approximately $37 \%$ (Ministry of Health, 2013). Stunting is one of the problems as a priority indicator of health development, so it must involve various sectors in the health sector. In 2015, 
$29 \%$ of Indonesian children under five were included in the short category (WHO, 2017).

Many efforts have been made to prevent stunting. The Government has tried to do prevention by monitoring the increase in Toddlers weighing in the Posyandu and making rescue efforts through the first 1000 days of life (HPK) (UNICEF 2018). Still, these efforts have not been maximally carried out so that it is necessary to improve the quality of care that is ongoing or continuum of care. Based on the Stunting Prevalence Data, the results of the weighing month toddlers Karawang Regency in 2017 increased to $15.1 \%$ compared to 2016 of $13.7 \%$. There are 13 Districts of 31 districts in Karawang that have a high Stunting prevalence, with an average percentage of 27.07\% (Maryam S, 2016). Understanding the situation needs to be considered for the best efforts by the government and health workers to reduce the number of stunting events so that the quality of human resources in Indonesia, in particular, Karawang Regency, is even better. Based on the background description, the researcher is interested in researching the continuum of care as an effort to reduce the incidence of stunting in the Karawang district.

\section{METHOD}

This research design using quantitative design and a cross-sectional survey approach. The data used are secondary and primary data. The research sample is Posyandu cadres in 25 Posyandu, consisting of 5 cadres / posyandu in 6 Karawang Community Health Centers. And The data collection techniques research include observation, interviews, and focus group discussions

(FGD).

\section{RESULTS AND DISCUSSION}

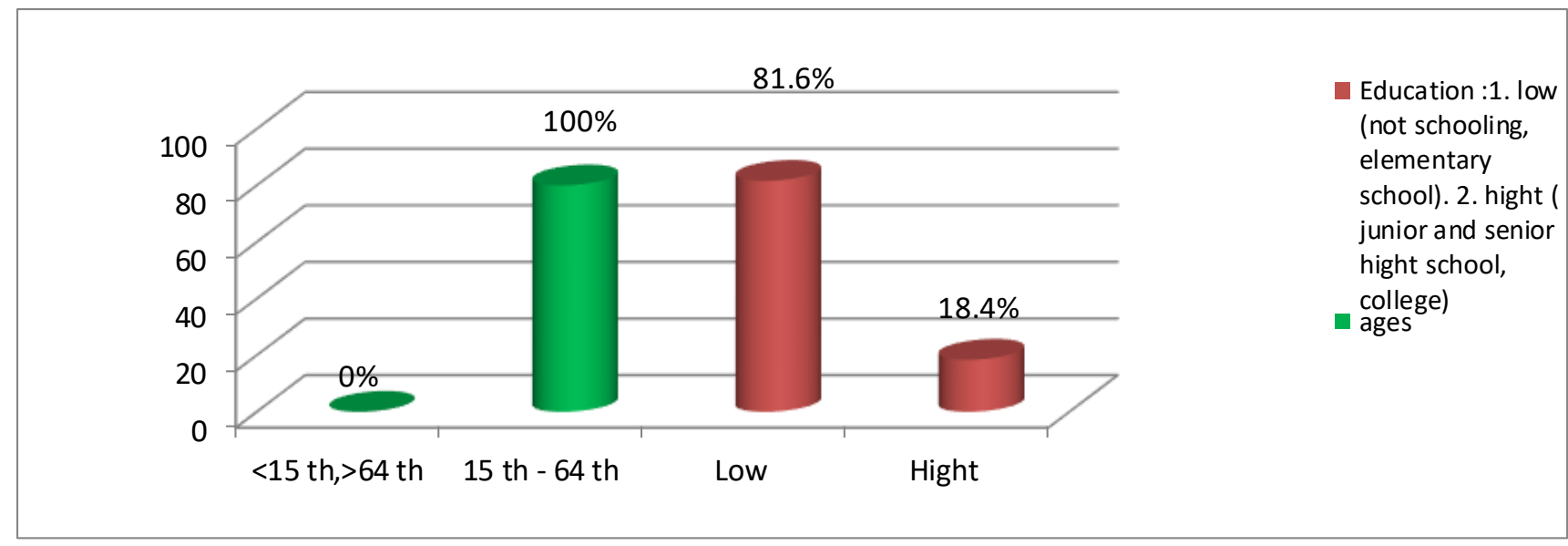

Diagram 1. Characteristics of respondents 
Based on the diagram above shows that $100 \%$ of the age of respondents in the group 15 th -64 th years, while the majority of respondents education was in a category not schooling and elementary school or loweducated at $81.6 \%$. The data shows that even though the age of the cadres is still productive, but their educational background is still low on average, they do not know about stunting due to the limited information they can get. This is consistent with the results of research conducted by Yulianti Eva (2010) that with proper knowledge, cadres can apply a variety of useful skills in carrying out prevention, early detection, and handling stunting.

Table 1. Continuum of care efforts to reduce the incidence of stunting in Karawang district 2019

\begin{tabular}{cllccc}
\hline No & Sub-district & $\begin{array}{c}\text { Community } \\
\text { Health Center }\end{array}$ & Stunting & $\begin{array}{c}\text { Continuum } \\
\text { of care }\end{array}$ & $\begin{array}{c}\text { Giving Care } \\
\text { place of } \\
\text { care } \\
\text { (posyandu) } \\
\text { Mean }\end{array}$ \\
\hline 1 & Tempuran & Lemah Duhur & 81,0 & 63,84 & 63,75 \\
2 & Tempuran & Tempuran & 15,8 & 78,70 & 80,74 \\
3 & CILEBAR & Kertamukti & 34,4 & 69,11 & 78,00 \\
4 & Telukjambe timur & Telukjambe & 4,3 & 80,29 & 82,86 \\
5 & Majalaya & Majalaya & 6,6 & 82,01 & 87,69 \\
6 & Karawang Barat & Tanjung Pura & 3,6 & 88,81 & 94,67 \\
\hline
\end{tabular}

Based on the table above, from the 6 Puskesmas work areas found that the Lemah duhur Public Health Center with a stunting incidence of $81 \%$ had a continuum of care on stunting less effective with an average of 63.84 and less available care centers with an average of 63.75. In contrast, effective care provision was in the working area of Tanjung Pura Health Center in West Karawang District. The average cadre who is not exposed to the care that must be done related to stunting, care that they have not known is how to detect the occurrence of stunting in infants and children and how to handle stunting. The problem is caused by the lack of information delivered by the Puskesmas, especially village midwives in stunting care, so that most cadres do not know how to do correct stunting care. As a result of these problems, the activities carried out at the posyandu were limited to weighing and administering PMT without providing comprehensive stunting care and many 
cases of toddlers and stunting children who were undetectable and did not get treatment from health workers.

Continuum of care has two dimensions: first, the provision of care, and second the place and approach of care delivery. This effectively links important maternal cycles, newborns, and child health, throughout adolescence, pregnancy, childbirth, the postnatal and newborn period and into childhood. They were building natural interactions throughout the entire life cycle. An effective set of treatments strengthens between homes and first-rate facilities, ensuring proper care is available in each place. Strategies involve increasing the skills of health workers, strengthening health system support, and improving community and community actions for health. Thus, by empowering health workers and optimal cadres, a series of proper care will occur, and stunting can be prevented (Sines E TA, Ruben J, 2006).

One routine poyandu activity for early detection of stunting on toddlers is to carry out a month of weighing on toddlers types of events carried out, such as give Vitamin A, measuring height and weighing, one of the officers carrying out these activities involves posyandu cadres. However, this activity was only carried out during August, so it was less able to detect stunting events each month (Dinkes Kab.Karawang, 2018). Whereas, based on the strategic plan, there are six policy directions, the six policy directions have the same role, such as nutrition improvement, to realize stunting reduction. The policy direction becomes a priority project and conducts continuous care (continuum of care) (Kerber KJ et al., 2007).

Based on the results of research that the prevention of stunting in posyandu has been carried out, including conducting the first 1000 days of life (HPK), such activities are through the class of pregnant women. Still, the activities that do most are only village midwives, while the involvement of cadres is limited to assisting. Cadre knowledge about stunting is still shallow, and even most cadres do not know what stunting is because many cadres have not received education or training on stunting. Cadre training on stunting has a positive impact on the ability of cadres to make early detection related to stunting. The provision of information will increase knowledge so that it can generate awareness and ultimately produce ways of thinking according to that knowledge so that there are behavioral changes following the knowledge possessed (Notoatmojo, 2010). According to cadre submission in several public health centers (Puskesmas) in Karawang, cadres only know the provision of supplementary food, 
measure height, body length, and weigh. Cadres do not know how to handle stunting, according to toddlers who experience stunting. Cadres do not do nutrition counseling activities and do not do simulation activities, detection, early intervention for child development, and deviations (SDIDTK) as an effort to manage tuned of children.

According to the Submission of the Family Health and Nutrition Section of the Karawang District Health Office, that crosssectoral support in the prevention and management of stunting has been carried The existence of cross-sector collaboration and programs in stunting prevention conducted by the Karawang regency government. The cooperation is divided into five pillars containing several policies including prevention of stunting being a priority of the government and society at all levels, increasing public awareness and changing people's behavior to prevent stunting, strengthening convergence through coordination and consolidation of central, regional and village programs and activities, strengthening cross-sectoral coordination and levels of government to the village level to ensure alignment in the provision and implementation of program implementation, meeting food and nutrition needs; by accelerating food diversification out, including a collaborative effort between Bapeda and the Health Office in the 2018 Rakerkesda activities, this program invited village heads, village health centers heads, nutrition departments, and Camat to reduce stunting with eight action plans to prevent stunting. One such plan is to create a cadre of stunting interventions. Other concrete activities carried out by the cross-sector, namely by carrying out the preparation of regional action plans in accelerating the prevention and handling of stunting, and these actions involve all regional apparatus organizations, hospitals, and health education institutions. based on local food resources and developing Sustainable Food Houses (KRPL), Access to nutritious food by ensuring affordability and availability of nutritious food.

The analysis of researchers found that there was a blockage in the delivery information that occurred from Puskesmas to posyandu cadres related to stunting so that the posyandu cadres did not know the overall information associated with stunting both from prevention and handling. Puskesmas working area in posyandu activities that involve cadres in reducing the incidence of stunting. 


\section{CONCLUSION}

Continuum of care in the giving of adequate care and place of care has the most significant impact on maternal health, the health of newborns and children related to the incidence of stunting in every region, especially in the Karawang public health centers. The existence of cross-sector collaboration and programs in stunting prevention conducted by the Karawang government. The key to the success of the partnership carried out across sectors, and cross programs in stunting prevention are seen from the success of receiving information obtained from cadres properly and evenly because cadres are the front lines in making efforts to reduce the incidence of stunting.

\section{REFERENCE}

Dinas Kesehatan Provinsi Jawa Barat. 2018. Pertemuan koordinasi bulan penimbangan balita Kabupaten Karawang.

Fikadu T, Assegit S, Dube L. 2014. Factors associated with stunting among children of age 24 to 59 months in Meskan district, Gurage Zone, South Ethiopia: a case-control study. $B M C$ Public Health. 14:1-7

Kerber KJ, Graft-Johnson J, Bhutta ZQA, Okong P, Starrs A, Lawn JE. 2007. Continuum of care for maternal, newborn, and child health: from slogan to service delivery. Lancet; 370: $1358-69$
Maryam S. 2016. Gizi dalam kesehatan reproduksi. Jakarta: Salemba medika.

Ministry of Health (MOH). 2013. Basic health research survey (Riset kesehatan dasar). Jakarta, Indonesia: National Institute of Research and Development, Ministry of Health

Kementerian Kesehatan. 2015. Rencana Strategis Kementerian Kesehatan tahun 2015-2019.

Sines E., Tinker A. Ruben J. 2006. The maternal-newborn-child health continuum of care: a collective effort to save lives. Washington, DC: Population Reference Bureau

TNP2K (Tim Nasional Percepatan Penanggulangan Kemiskinan). 2017. 100 Kabupaten/Kota Prioritas untuk Intervensi Anak Kerdil (Stunting). Jakarta: Tim Nasional Percepatan Penanggulangan Kemiskinan.

UNICEF, WHO, World Bank. 2012. Levels and Trends in Child Malnutrition: Joint Child Malnutrition Estimates. New York, NY: United Nations International Children's Fund; Geneva: WHO; Washington, DC: World Bank. Available from:http://www.who.int/nutgrowthdb lestimates/en/

UNICEF. 2013. Improving Child Nutrition The Achievable Imperative for Global Progress.

UNICEF, WHO. 2018.World Bank Joint Child Malnutrition dataset, May

Wobay A, Member Y, Tsegaye D. 2017. Prevalence of and associated Factors of stunting among adolescents in tehuledere district, North East Ethiopia, 2017. Journal of Clinical \& Cell Immunology. 9(2):1-8. 
World Health Organization, Regional Office for South-East Asia. 2017. The Republic of Indonesia Health System Review. Health Systems in Transition: 7(1)

Yulianti Eva. 2010. Pelatihan kader kesehatan deteksi dini stunting pada balita di Desa Betteng. Tesis. 